BIOMEDICAL AND BIOSOCIALANTHROPOLOGY
Official Journal of the International Academy
of Integrative Anthropology
journal homepage: http://bba-journal.com

\title{
Determination of individual angular characteristics of the teeth positions according to the computer tomography in Ukrainian adolescents with orthognathic bite
}

Dmitriev M. O. ${ }^{1}$, Volkov K. S. ${ }^{2}$, Glushak A. A. ${ }^{1}$, Kyrychenko Yu. V. ${ }^{1}$, Balynska M. V. ${ }^{1}$, Chugu T. V. ${ }^{1}$, Kovalchuk O. I. ${ }^{3}$

${ }^{1}$ National Pirogov Memorial Medical University, Vinnytsya, Ukraine

2SHEE "Ternopil Ivan Horbachevsky State Medical University of the Ministry of Healthcare of Ukraine", Ternopil, Ukraine ${ }^{3}$ Shupyk National Medical Academy of Postgraduate Education, Kyiv, Ukraine

\section{ARTICLE INFO}

Received: 13 March, 2018

Accepted: 27 April, 2018

UDC: $616.716 .8-071-084: 613.956$

617.52: $616.34 .25-007.481-7$

\section{CORRESPONDING AUTHOR}

e-mail:dmitriyevnik@gmail.com Dmitriev M. O.
The lack of the ability to determine the individual standard angle characteristics of the position of the teeth and the technical provision of their control often does not lead to the expected result and in each case requires individualization, the vision of which is based, as a rule, on the experience and intuition of the doctor. In order to solve such a situation, in addition to improving the positioning protocols of the non-removable equipment, the physician should be able to clearly identify the individual angular characteristics of the tooth-jaw system. The purpose of the study - by studying computer tomography and cephalometric indices and conducting direct stepwise regression analysis to develop in Ukrainian adolescents with orthognathic bite mathematical models of individual angular positions of teeth. Using the Veraviewepocs $3 D$ device, Morita (Japan) at 38 young men (aged from 17 to 21) and 55 young women (aged from 16 to 20 years) with normal occlusion close to orthognathic bite received and analyzed dental tomograms and lateral teleroentgenograms. Cephalometric points and measurements were performed according to recommendations of A. M. Schwarz, J. McNamara, W. B. Downs, R. A. Holdway, G. P. F. Schmuth, C. C. Steiner and C. H. Tweed. Anatomical points were determined taking into account the recommendations of $A$. E. Athanasiou, S. I. Doroshenko and Y. A. Kulginsky. The simulation of CT indexes describing the position of individual teeth relative to each other, to the bone cranial structures and the profile of adolescents with orthognathic bite, depending on the metric characteristics of the skull, which are usually unchanged during surgical and orthodontic treatment, as well as the width, lengths, angles and positions of the upper and lower jaws that may be altered by orthodontic surgery done. The statistical processing of the obtained results was carried out in the license package "Statistica 6.0" using a direct stepwise regression analysis. It was found that in young men of 40 possible models, 23 were constructed with a determination coefficient $R^{2}$ of 0.557 to 0.832 , while in young women, only 8 models with a determination coefficient $R^{2}$ of 0.581 to 0.832 . Moreover, in the young men - of 10 possible 9 models of vestibular-tongue inclination of corresponding teeth ( $R^{2}$ from 0.557 to 0.832 ) were constructed; out of 10 possible 5 models of mesio-distal inclination of corresponding teeth ( $R^{2}$ from 0.558 to 0.769 ) constructed; of the possible 14 constructed 6 models of rotation of the corresponding teeth ( $R^{2}$ from 0.579 to 0.737 ); and in young women - there are only 5 models of vestibular-tongue inclination of the corresponding teeth ( $R^{2}$ from 0.603 to 0.665 ). In addition, in both young men and young women, models of the size of the inter-incision angle $\left(R^{2} 0.748\right.$ in young men and 0.581 in young women) were constructed, the magnitude of the angle of inclination of the lower canine in the jet plane ( $R^{2}$ respectively 0.729 and 0.793), and the magnitude of the inclination of the closure planes relative to the palatal plane $\left(R^{2}\right.$ respectively 0.808 and $0.832)$. In the analysis it was found that in young men, most frequently models included - indicator WITS (7.0\%); angle GL SNPOG (5.4\%); distance S E, angle MM, angle NSBA (by 4.7\%); angle AB_NPOG, angle N_POG_, distance N_SE, coefficient N_SP_SP, 
angle P_OR_N (by 3.9\%). In young women, most frequently models included - angle N_POG_(14.3\%); angle AB_NPOG (10.2\%); indicator WITS (8.2\%); angle MM, angle $A \bar{N} B$, length of the branch of the mandible R_ASC (by 6.1\%). Thus, in the work with the help of the method of step-by-step regression with inclusion, among Ukrainian adolescence, on the basis of peculiarities of computer-tomographic and teleroentgenography indices, reliable models of computer-tomographic individual linear angular characteristics of the position of teeth necessary for constructing the correct three-dimensional geometry of dental arches are developed and analyzed.

Keywords: regression analysis, vestibular-lingual tilt of the tooth (tork), mesiodistal inclination of the tooth (angulation), tooth rotation (rotation), computed tomography, teleroentgenography, young men, young women, orthognathic bite.

\section{Introduction}

Cone-ray computed tomography provides significant advantages for working with images in orthodontics, allows you to describe the craniofacial anatomy more precisely and provide comprehensive information on anatomical relationships and individual patient characteristics for improved diagnosis, treatment planning and prediction of dental anomalies [5, 19, 23]. But the lack of standard assessment methods, the unified protocol of orthodontic research, the existence of various methods for obtaining a three-dimensional image and the impossibility of their association defines a set of tasks that need to be resolved for the widespread introduction of computed tomography into orthodontic and surgical practice [28]. The issues of determining and controlling the three-dimensional position of the teeth have always been central to clinical orthodontic practice. The main characteristics of the position of the central axis of the tooth in the form of various sets of standard characteristics formed the basis of the production of bracket systems in the form of a prescription, which determines the position of the tooth in relation to the orthodontic arc [21].

Difficulties in production, individual morphological variety of teeth, different variants of positioning lead to the fact that the doctor often fails or difficult to implement the bracketed angular characteristics. The lack of the ability to determine the individual standard angle characteristics of the position of the teeth and the technical provision of their control often does not lead to the expected result and in each case requires individualization, the vision of which is based, as a rule, on the experience and intuition of the doctor. In order to solve such a situation, in addition to improving the positioning protocols of the non-removable equipment, the physician should be able to clearly identify the individual angular characteristics of the tooth-jaw system.

The purpose of the study - by studying computer tomography and cephalometric indices and conducting direct stepwise regression analysis to develop in Ukrainian adolescents with orthognathic bite mathematical models of individual angular positions of teeth.

\section{Materials and methods}

Dental tomograms and side teleroentgenograms were obtained and analyzed using the Veraviewepocs 3D device, Morita (Japan) in 38 young men (17 to 21 years of age) and 55 young women (aged 16 to 20 years) with normal occlusion close to orthognathic bite. Cephalometric points and measurements were performed according to recommendations of A. M. Schwarz, J. McNamara, W. B. Downs, R. A. Holdway, G. P. F. Schmuth, C. C. Steiner and C. H. Tweed $[11,14,15,24,29,30,31,33]$. Anatomical points were determined taking into account the recommendations of $A$. $E$. Athanasiou [3], S. I. Doroshenko and Y. A. Kulginsky [10].

The analysis of telerentgenograms and the results of their researches for Ukrainian adolescents are described in detail and set out in a number of articles [6, 7, 8, 9, 12, 13]. The determined cephalometric indices were combined and then divided into three groups. The first group included metric characteristics of the skull, which usually do not change during surgical and orthodontic treatment. Most of these

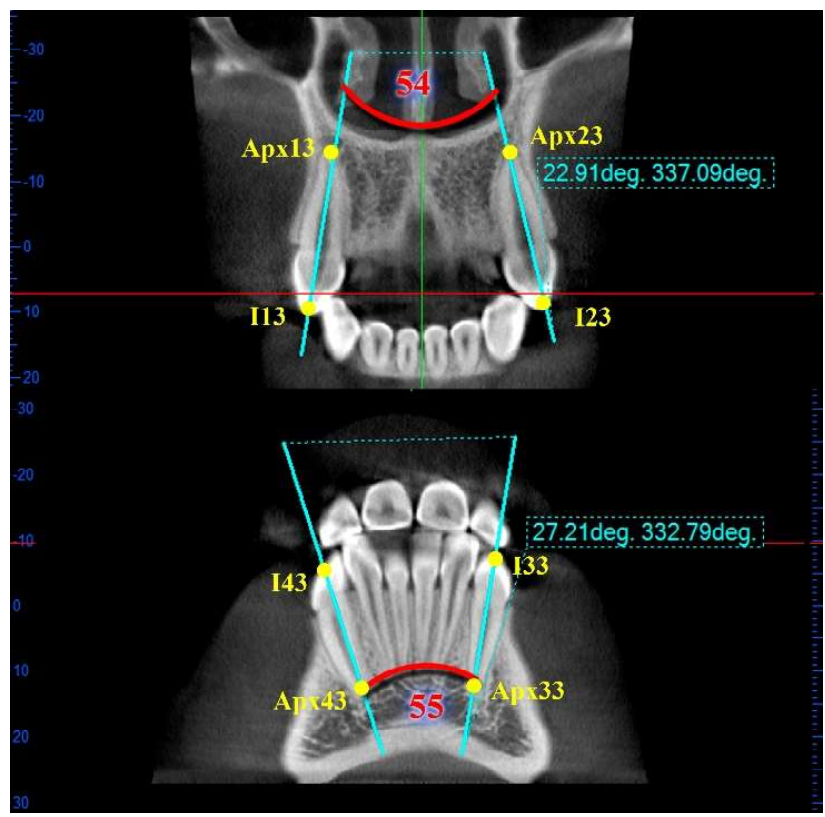

Fig. 1. The angle between the central canines axis of the jaw of the upper jaw in the frontal projection (54) (YG13_23) - formed by lines I13-Apx13 and I23-Apx23 in the frontal projection; the angle between the central axis of the jaw of the lower canines in the frontal projection (55) (YG33_34) - formed by lines I33-Apx33 and 143-Apx43 in the frontal projection. Here and thereafter: - Apx (apex) - the top of the root of the corresponding tooth; I - the middle of the cutting edge of the corresponding tooth. 


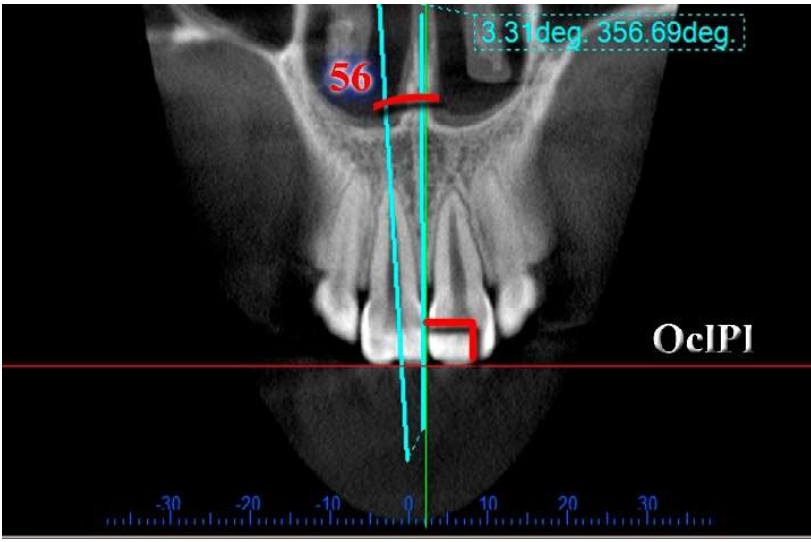

Fig. 2. Mesio-distal inclination !! of the corresponding tooth (56) (ANGUL !!) - formed by line !!!-Apx!! (the central axis of the corresponding tooth) and perpendicular to the closure plane (OcIPI) in the frontal area of the studied tooth (in the calculation the average value of the angle of the symmetrical teeth of the right side to left side on one jaw is then taken).

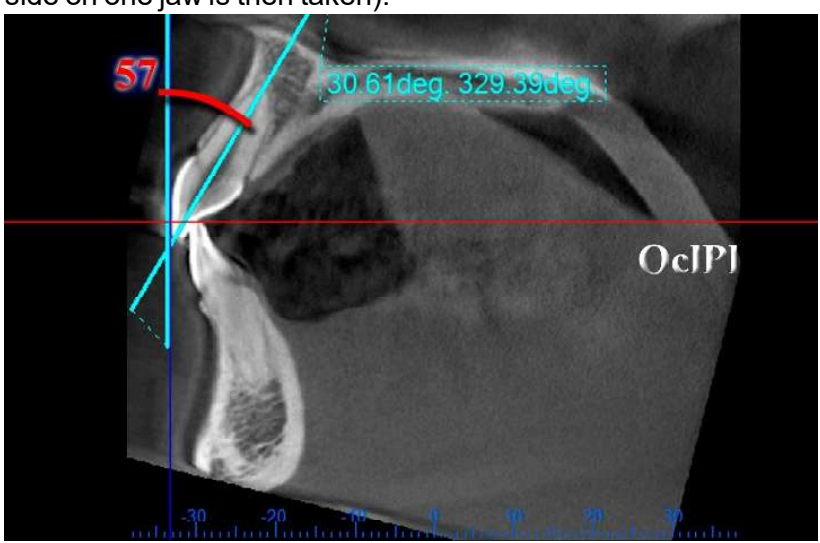

Fig. 3. Vestibular-lingual inclination !! of the corresponding tooth (57) (TORK!!) - formed by line I!!-Apx!! (the central axis of the corresponding tooth) and perpendicular to the closure plane (OcIPI) in a sagittal plane of investigating tooth (in the calculation the average value of the angle of the symmetrical teeth of the right side to left side on one jaw is then taken).

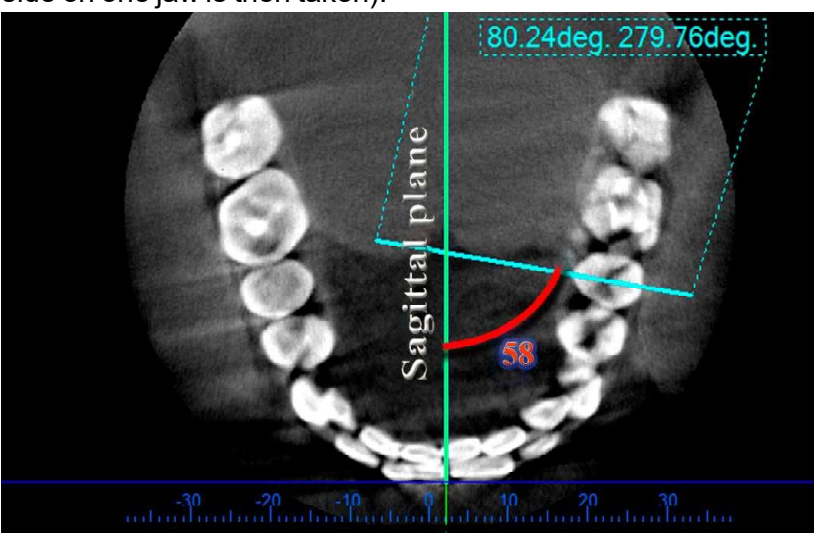

Fig. 4. Rotation!! of the corresponding tooth (58) (ROT!!) - formed by the median-sagittal plane of the tooth and the median-sagittal plane of the head, allows to determine the tooth rotation relative to the median-sagittal plane (in the calculation the average value of the angle of the symmetrical teeth of the right side to left side on one jaw is then taken).

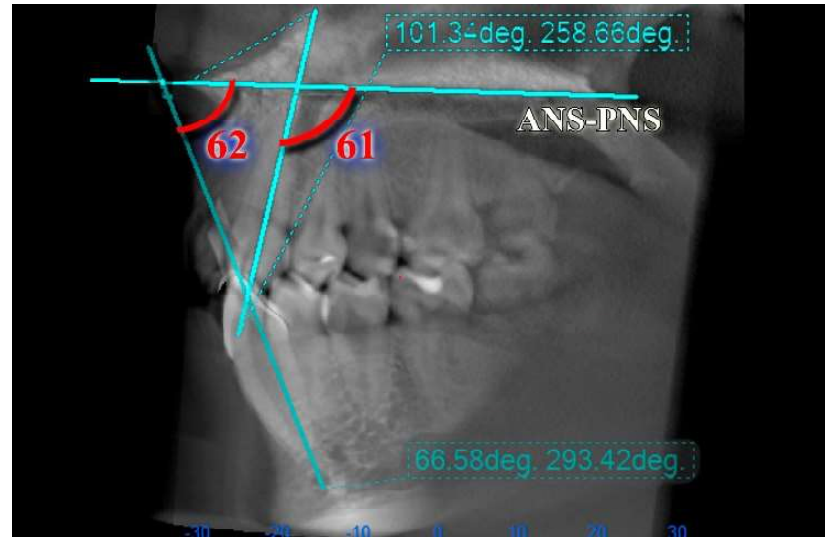

Fig. 5. Angle of inclination of the upper canine in the sagittal plane (61) (MDYG13) - formed by lines I13-Apx23 and line ANS-PNS in the sagittal projection (the angle formed by the central canine axis of the upper jaw and the palatal plane in the sagittal projection); angle of inclination of the lower canine in the sagittal plane (62) (MDYG33) - formed by lines 143-Apx43 and line ANS-PNS in the sagittal projection (the angle formed by the central canine axis of the lower jaw and the palatal plane in the sagittal projection).

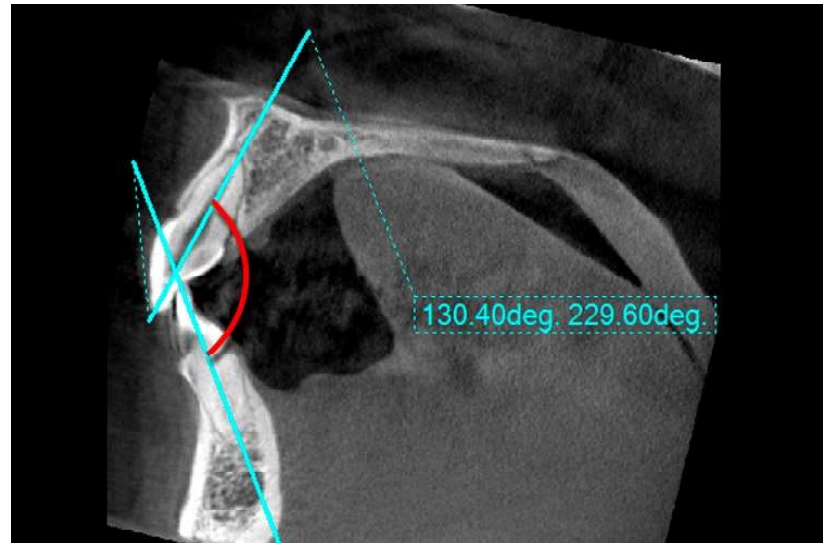

Fig. 6. Inter-cutter angle (YGRES) - formed by the central axes of the middle incisors of the upper I11-Apx11 and lower jaws I41Apx41 (the indicator characterizes the angle formed by median cutters of the upper and lower jaws in the sagittal projection), (the calculation takes averaged magnitude of the angle of the symmetrical teeth of the right and left sides on one jaw).

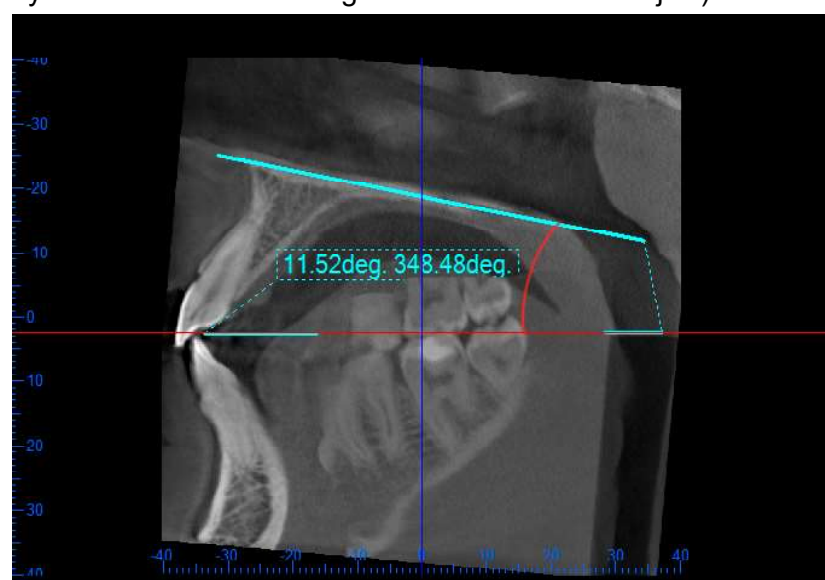

Fig. 7. Determination of the inclination of the closure plane relative to the palatal plane. 


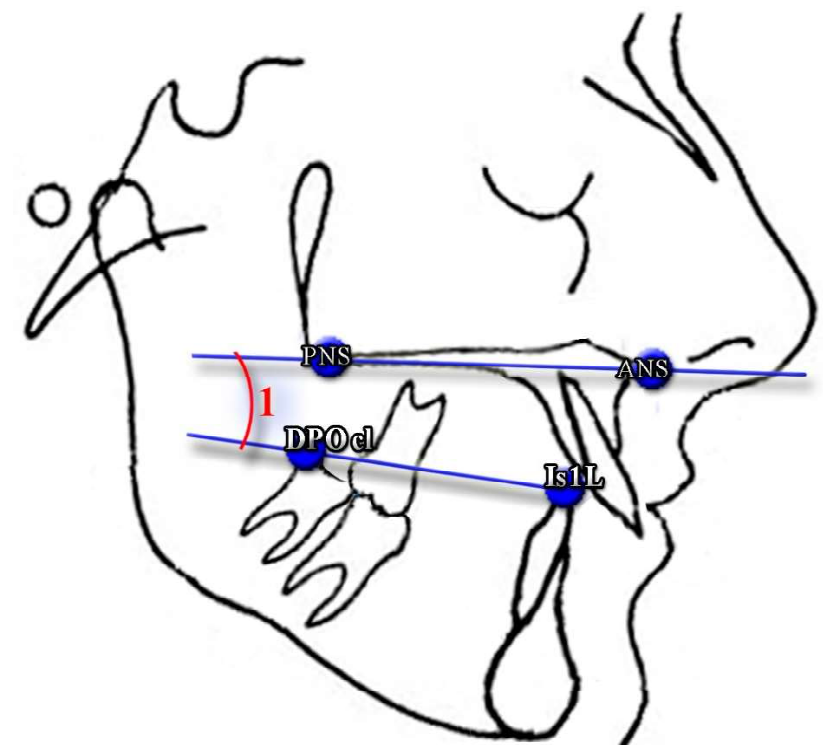

Fig. 8. Determination of the inclination of the closure plane on the teleroentgenogram relative to the palatal plane. 1 - the angle of inclination of the closure plane in contact with the cutting edge of the median lower incisors (Is $1 \mathrm{~L}$ ) and the further buccal edges of second molars of the mandible (DPOcl) relative to the palatal plane that passes through the point passing through the anterior (ANS) and posterior (PNS) nasal spine.

indicators are basic in modern cephalometric analyzes. In relation to them, lateral teleroentgenograms determine the inclination, anterior-posterior or vertical position of the gnatic structures (upper and lower jaw, closure plane, separate teeth). The second group includes indicators of the toothjaw system, the definitions of which most often need to be oriented when performing orthodontic treatment of patients who are in the process of growth, as well as in individuals with a formed bone skeleton who may with orthodontic surgery change the width, length, angles and positions of the upper and lower jaws. The third group includes indicators that actually characterize the position of each individual tooth relative to each other, to the bony cranial structures and profile of the face. It is this group of indicators most often corrected in the process of orthodontic treatment of tooth-jaw abnormalities.

For modeling, we selected the following CT-indicators of the third group (Fig. 1-6), depending on the characteristics of the indicators of the first and second groups.

For a more universal clinical use, the position of the occlusion plane in relation to the palatine plane was investigated (YGOCLPL). This indicator can be determined both on dental tomograms on and on teleroentgenogrami (Fig. 7 and 8).

The statistical processing of the obtained results was carried out in the license package "Statistica 6.0" using a direct stepwise regression analysis. In the case of direct stepwise regression analysis, we have identified several conditions: 1) - the final version of the regression polynomial must have a determination coefficient of not less than 0.50 , that is, the accuracy of the description of the feature being simulated is not less than $50.0 \% ; 2$ ) - the value of the Fcriterion is not less than 3.0 , that is, the contribution of the variable to the regression should be sufficiently significant; 3 ) - the number of free members included in the polynomial should be as low as possible. In all cases, after selecting the equation of multiple regression, we carried out the analysis of the residues, since emissions can substantially shift the results and lead to erroneous conclusions. When the observations fell beyond the \pm 3 standard quadratic deviations from the mean value, we carried out a repeated analysis with and without emissions, in order to be sure that their impact on the bias of the final results is not affected.

\section{Results}

Results of simulation of CT indicators that characterize the position of individual teeth relative to each other, to the bone cranial structures and the profile of the appearance in young men and women with orthognathic bite, depending on the metric characteristics of the skull, which usually do not change during surgical and orthodontic treatment, as well as indicators of width, length, angles and positions of the upper and lower jaws that may be altered by orthodontic surgery, have the form of the following linear equations.

\section{For young men:}

TORK_11 $=-10.08+1.190 \times$ AB_NPOG $-0.344 \times \mathrm{T}+$ $0.282 \times G+0.244 \times$ N_POG_+ $0.662 \times$ WITS $+0.121 \times$ N_SE $\left(R^{2}=0.645 ; F_{(6,29)}=8.80 ; p<0.001 ;\right.$ Error of estimate $\left.=2.780\right)$;

TORK_12 $=47.84+1.546 \times A B \_N P O G+0.417 \times P N \_A-$ $0.662 \times$ S_E - $1.027 \times$ MAX_MAND + $0.497 \times A F H\left(R^{2}=0.557\right.$; $F_{(5,30)}=7.53 ; p<0.001 ;$ Error of estimate $\left.=3.040\right)$;

TORK_13 $=57.67-0.395 \times$ N_POG_- $0.780 \times$ NL_NSL $0.422 \times$ LPALAT $-0.576 \times$ WITS $-0.342 \times$ COND_GN +0.460 $x$ N_SE $\left(R^{2}=0.604 ; F_{(6,29)}=7.36 ; p<0.001\right.$; Error of estimate $=2.791$;

TORK $14=-21.60+1.188 \times \mathrm{PFH}+0.577 \times \mathrm{FMA}-0.769 \mathrm{x}$ COND_GN $+0.472 \times$ SND + $1.095 \times$ ML_NL $-0.769 \times \mathrm{B}$ $\left(R^{2}=0.832 ; F_{(6,29)}=23.96 ; p<0.001 ;\right.$ Error of estimate=1.885); TORK_15 $=6.657-0.920 \times$ COND_A + $0.329 \times \mathrm{PFH}+$ $0.848 \times$ N_SE $+1.760 \times$ SNA $-0.368 \times$ MAND $-1.310 \times \mathrm{F}$ $\left(R^{2}=0.715 ; F_{(6,29)}=12.11 ; p<0.001\right.$; Error of estimate=2.628);

TORK_41 $=-6.068+1.718 \times$ WITS + $0.743 \times$ COND_A $0.551 \times$ ANS_ME $\left(R^{2}=0.719 ; F_{(3,32)=} 27.23 ; p<0.001\right.$; Error of estimate $=3.955)$;

TORK_42 $=-47.98-0.938 \times A B \_N P O G-1.314 \times$ ML_NSL $+0.685 \times$ S_E $+0.373 \times$ N_POG_ $+0.509 \times$ NBA_PTGN + $1.276 \times$ SN_GOGN $\left(R^{2}=0.815 ; F_{(6,29)}=21.25 ; p<0.001\right.$; Error of estimate $=2.612$ );

TORK_43 $=-121.5+0.664 \times \mathrm{MM}-2.228 \times \mathrm{ML} \_\mathrm{NSL}+$ $1.823 \times$ SN_GOGN + 0.240 x MAX + $0.218 \times$ NSBA + $0.362 \times$ $G\left(R^{2}=0.762 ; F_{(6,29)}=15.48 ; p<0.001 ;\right.$ Error of estimate=2.360);

TORK_44 $\stackrel{-6,29}{=} .185-0.353 \times \mathrm{G}+0.670 \times \mathrm{NSBA}+0.443 \times$ GL_SNPOG - $0.548 \times \mathrm{H}+0.216 \times \mathrm{PFH}\left(\mathrm{R}^{2}=0.739\right.$; $F_{(5,30)}=16.99 ; p<0.001$; Error of estimate $\left.=2.487\right)$;

ANGUL_12 $=-71.25+0.507 \times$ ARGOME $+0.586 \times$ MAND $+0.478 \times$ WITS $-0.191 \times$ GL_SNPOG $-0.218 \times$ COND_GN 
$\left(R^{2}=0.558 ; F_{(5.30)}=7.56 ; p<0.001 ;\right.$ Error of estimate=2.158); ANGUL_15 $=-131.0+0.592 \times$ AB_NPOG $+1.426 \times \mathrm{T}+$ $0.152 \times$ GL SN S + 0.144 x AFH + $1.398 \times$ SND $-0.740 \times$ GL_SNPOG $\left(R^{2}=0.664 ; F_{(6,29)}=9.55 ; p<0.001\right.$; Error of estimate $=2.359)$;

ANGUL_42 $=-52.29+0.766 \times$ LPALAT $+0.232 \times \mathrm{H}-0.115$ $x$ N_SP_SP $+0.283 \times$ WITS $-0.420 \times$ MAX $+0.246 \times$ N_SE $\left(R^{2}=0.574 ; F_{(6,29)}=6.51 ; p<0.001 ;\right.$ Error of estimate $\left.=2.090\right)$;

ANGUL_43 $=-34.83+0.526 \times$ LPALAT $+0.288 \times$ MM $0.140 \times \operatorname{NSBA}\left(R^{2}=0.606 ; F_{(3,32)}=16.38 ; p<0.001\right.$; Error of estimate $=2.012$ );

ANGUL_44 $=-77.29+0.879 \times \mathrm{MM}+1.098 \times \mathrm{MAX}-0.404$ $x$ MAND - $0.549 \times$ S_E + $0.850 \times$ AB_NPOG $-0.362 x$ MAX_MAND $\left(R^{2}=0.769 ; F_{(6,29)}=16.10 ; p<0.001\right.$; Error of estimate $=2.344)$;

ROT_13 $=-314.4-1.435 \times \mathrm{MM}+1.536 \times \mathrm{ANB}+0.537 \times$ $\mathrm{NSBA}+1.176 \times \mathrm{WITS}+2.883 \times \mathrm{POR}$ GNS $+2.342 \times \mathrm{P} \_\mathrm{OR} \_\mathrm{N}$ $+0.589 \times$ N_SP_SP $\left(R^{2}=0.629 ; F_{(7,28)}=6.78 ; p<0.001\right.$; Error of estimate $=5.201)$;

ROT_14 $=59.46+0.914 \times \mathrm{NL}$ NSL $+0.912 \times \mathrm{S} \_\mathrm{E}-$ $0.384 \times \mathrm{H}+0.259 \times$ N_SP_SP $-0.481 \times \mathrm{GL}$ SNPOG +0.473 $x$ N_POG_ $\left(R^{2}=0.601 ; F_{(6,29)}=7.27 ; p<0.001\right.$; Error of estimate $=4.229$ );

ROT_15 $=25.43+0.897 \times \mathrm{NL}$ NSL $+1.075 \times \mathrm{S} \_\mathrm{E}+$ $1.064 \times$ SNA - $1.839 \times$ ANS_ME + $1.604 \times$ AFH - $0.648 \times$ SND $\left(R^{2}=0.737 ; F_{(6,29)}=13.57 ; p<0.001\right.$; Error of estimate=2.842);

ROT_16_1 $=114.5-0.313 \times$ GL_SN_S $+0.443 \times$ N_SP_SP - $0.496 \times$ GL_SNPOG $-0.253 \times$ MAX_MAND $\left(R^{2}=0.579 ; F_{(4,31)}=10.64 ; p<0.001\right.$; Error of estimate=3.456);

ROT_41 $=-34.74+1.121 \times$ N_POG_- $_{-} 0.636 \times$ GL_SNPOG $+2.980 \times$ POR_NPOG $-2.311 \times P \_O R \_N-0.735$ $x$ NL_NSL - $0.202 \times$ AFH_PFH $\left(R^{2}=0.593 ; F_{(6,29)}=7.03\right.$; $p<0.001$; Error of estimate $=3.247$;

ROT $46=-54.92+1.713 \times$ POR NPOG $-0.855 x$ COND_A + $1.128 \times$ N_SE $+0.335 \times$ NSBA $+0.599 \times$ SNA $1.334 \times$ P_OR_N $\left(R^{2}=0.589 ; F_{(6,29)}=6.92 ; p<0.001\right.$; Error of estimate $=2.711$ )

MDYG33 $=201.1-1.238 \times$ MM $-0.500 \times S E-1.507 \times$ POR_NPOG + $1.258 \times$ WITS $+0.304 \times G+1.059 \times P \_O R \_N$ $\left(R^{2}=0.729 ; F_{(629)}=13.01 ; p<0.001\right.$; Error of estimate=3.573);

YGOCLPL $=-33.59-0.224 \times$ N_SP_SP $-0.981 \times$ WITS + $0.465 \times \mathrm{T}+0.109 \times \mathrm{GL}$ SN_S + $0.439 \times \mathrm{MM}-0.167 \times$ GL_SNPOG $\left(R^{2}=0.808 ; F_{(6,29)}=20.35 ; p<0.001\right.$; Error of estimate=1.858);

YGRES $=168.8-1.002 \times$ S_L $-1.337 \times$ WITS $-0.477 \times$ $\mathrm{NSBA}+0.837 \times$ ANS_ME $+0.806 \times \mathrm{P} \_$OR_N $-0.437 \times \mathrm{R} \_\mathrm{ASC}$ - $1.005 \times$ ML_NL $\left(R^{2}=0.748 ; F_{(7,28)}=11.88 ; p<0.001\right.$; Error of estimate $=3.653$ );

where, here and in the future, $R^{2}$ - coefficient of

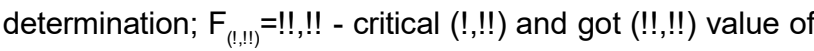
Fisher's criterion; St. Error of estimate - standard error of the standardized regression coefficient; AB_NPOG - angle formed by lines A-B and N-Pog, (defines the position of the plane $A B$ in relation to $\mathrm{N}$-pog); $\mathbf{T}$ (profile angle $\mathrm{T}$ ) - is formed by lines $\mathrm{Sn}$-Pog' and $\mathrm{Pn}$ (nasal perpendicular, perpendicular to the line from the point $\mathrm{N}^{\prime}$ to the line Se-N); $\mathbf{G}$ (angle $\mathrm{G}$, gonial angle, mandibular angle) - is formed by lines ppCondMT2 and T2-Me, which intersect at the point tGoS; N_POG_ (angle N'Hold_Pog'_Hline) - the angle between the lines Ls-Pog' (H line, Holdway line) and N'Hold-Pog'; WITS (Wits indicator) - the distance between the constructive points AOcIP and BOcIP (indicates a linear intra-jaw ratio in the anteriorposterior direction); N_SE (distance Se_N or the length of the front of the skull base by Steiner) - distance from the point Se to the point N; PN_A (distance PN_A) - distance from the point $A$ to the line $P N m$ (perpendicular line from the point $\mathrm{N}$ to the line Po-Or); S_E (distance S_E or the length of the back of the skull base by Steiner) - distance from the point $S$ to a constructive point $E$, which is located at the crossroads of the perpendicular conducted from the point ppCond to the line S-N; MAX_MAND (maxillo-mandibular difference) - difference between distances Cond-A (42') and Cond-Gn (42"); AFH (distance AFH or front height of the face) - distance from the point Me to the line ANS-PNS; NL_NSL (angle NL_NSL, also angle SNSpP) - is formed by lines ANS-PNS and S-N (angle of the palatal plane to the base of the skull inclination); LPALAT (the size of the base of the upper jaw) - distance between points ANS and PNS; COND GN (effective length of mandible, or distance COND_GN) - distance from the point Cond to the point $\mathrm{Gn}$; PFH (distance PFH or back height of the face) - distance from the point Ar to the point tGo; FMA (POr_MeGo, angle FMA, Frankfort Mandibular Angle) - is formed by lines tGo-Me (mandibular plane Mp) та Po-Or (Frankfurt plane Fp); SND (angle SND) - is formed by lines S-N and N-D (indicates the anterior-posterior arrangement of the symphysis of the mandible to the base of the skull); ML_NL (SpP_GoMe, base angle) - is formed by lines ANS-PNS and tGo-Me (the angle between the palatal SpP and the mandibular MP planes); B (base angle) - is formed by lines ANS-PNS (palatine plane $\mathrm{SpP}$ ) and Im-Me (mandibular plane MPS by Schwarz) (indicates the angle between the upper and lower jaws); COND_A (effective length of the upper jaw) - distance from the point Cond to the point A; SNA (angle SNA) - is formed by lines $\mathrm{S}-\mathrm{N}$ and $\mathrm{N}-\mathrm{A}$, (the angle indicates the anterior-posterior position of the upper jaw to the base of the skull); MAND (length of mandible) - distance from the constructive point tGoS to the constructive point apMandS; $F$ (facial angle or angle $\mathrm{F}$ ) - is formed by lines Se-N and N-A (determines the location of the anterior contour of the upper jaw in the jet plane to the base of the skull); ANS_ME (lower face height) - distance from the point ANS to the point Me; ML NSL (angle ML_NSL or angle SN_GoMe) - is formed by lines tGo-Me and $\mathrm{S}-\mathrm{N}$, (inclination angle of the mandibular plane to the base of the skull); NBA_PTGN (angle NBa-PtGn or the angle of the front axle) - is formed by lines N-Ba and Pt-Gn (determines the direction of development of the mandible); SN_GOGN (angle SN_GoGn) - is formed by lines Go-Gn and S-N (inclination angle of the lower jaw plane by Steiner, to the base of the skull); MM (maxillo-mandibular angle) - is formed by lines A-B and ANS-PNS (defines the angle at which the upper jaw is located in relation to the lower jaw in the jet 
plane); MAX (length of the upper jaw) - distance from the constructive point apMax to the point PNS; NSBA (angle NSBA) - is formed by lines S-N (the front part of the skull base) and S-Ba; GL_SNPOG (angle GI'SnPog' or index of convexity of the soft tissue profile) - is formed by lines Gl'-Sn and SnPog'; $\mathbf{H}$ (H-angle) - is formed by lines Po-Or (Frankfurt plane) and $\mathrm{Pn}$ (nasal perpendicular, perpendicular to the line from the point $\mathrm{N}^{\prime}$ to the line Se-N), defines the angle of inclination of the Frankfurt plane to the base of the skull; ARGOME (angle Ar-Go-Me, or the angle of the lower jaw) - is formed by lines Ar-tGo and tGo-Me; GL_SN_S (index Gl'_Sn_Sn_Gn' or facial vertical index) - distance ratio Gl'-Sn and $S n-G n$ ' (defines vertical relationships in the face profile); N_SP_SP (coefficient N_Sp'_Sp'_Me) - distance ratio N-Sp' and Sp'-Me (ratio of the upper and lower height of the face); ANB (angle ANB) - is formed by lines A-N and N-B (indicates an angular interstitial relationship in the anterior-posterior direction); POR_GNS (Y-axis or angle POr_GnS) - angle formed by lines Po-Or and $S-G n$ (angle of inclination of the $Y$-axis relative to the Frankfurt plane); $\mathbf{P}$ _OR_N (a soft tissue face angle, or an angle P_Or_N'Hold_Pog') - is formed by lines Po-Or and N'Hold-Pog'; POR_NPOG (angle POr_NPog) - is formed by lines Po-Or and N-Pog; AFH_PFH (AFH_PFH ratio) - ratio between the values of the front $(\mathrm{AFH})$ and the rear $(\mathrm{PFH})$ face height; S_L (distance S_L or the anterior length of the base of the skull by Steiner) - from point $S$ to a constructive point $L$, which is formed at the intersection of the perpendicular carried out from the point Pog to the line Se-N; R_ASC (length of the branch of the mandible) - distance from the constructive point R.asc to the constructive point tGoS.

\section{For young women:}

TORK_11 $=27.88-3.342 \times \mathrm{SNB}+2.777 \times \mathrm{AB} \_\mathrm{NPOG}+$ $3.744 \times$ ANB $+2.773 \times$ SND $+0.841 \times$ N_POG_ + $0.540 \times$ NBA_PTGN - $0.382 \times \mathrm{T}\left(\mathrm{R}^{2}=0.615 ; \mathrm{F}_{(7,43)}=9.80 ; \mathrm{p}<\overline{0} .001\right.$; Error of estimate $=3.223)$;

TORK_41 $=25.54+2.068 \times$ WITS $+0.574 \times$ N_POG_$0.261 \times$ N_SP_SP $+0.292 \times \mathrm{R} \_A S C+1.814 \times A B \_\bar{N} P O G+$ $2.255 \times \overline{A N B}\left(R^{2}=0.665 ; F_{(6,44)}=14.55 ; p<0.001\right.$; Error of estimate $=4.122)$;

TORK_42 $=-80.78+1.768 \times$ WITS $+0.868 \times$ N_POG_+ $0.601 \times \mathrm{I}+0.466 \times \mathrm{H}-0.275 \times$ GL_SNPOG $\left(\mathrm{R}^{2}=0.6 \overline{5} 6\right.$; $F_{(5,45)}=17.17 ; p<0.001$; Error of estimate $\left.=3.504\right)$;

TORK_43 $=24.53+0.531 \times$ WITS $+0.552 \times$ N_POG_+ $0.673 \times$ N_SE - $0.264 \times$ POR_GNS - $0.419 \times$ MAND $-0.11 \overline{8} \times$ ARGOME $\left(R^{2}=0.636 ; F_{(6,44)}=12.79 ; p<0.001\right.$; Error of estimate $=2.762)$;

TORK_44 $=-78.70+0.537 \times \mathrm{MM}+0.160 \times \mathrm{GL}$ SN_S + $1.959 \times \mathrm{NAPOG}+1.116 \times \mathrm{AB} \_\mathrm{NPOG}+0.271 \times \mathrm{COND}$ A $3.106 \times$ A_N_PO $\left(R^{2}=0.603 ; F_{(6,44)}=11.12 ; p<0.001\right.$; Error of estimate $=2 . \overline{7} 96)$;

MDYG33 $=308.7-1.755 \times$ MM $-0.896 \times$ N_POG_- 1.372 $x A B \_N P O G-0.243 \times R \_A S C-0.355 x$ NBA_PTGN-0.196x N_SP_SP $\left(R^{2}=0.793 ; F_{(6,44)}=28.02 ; p<0.001\right.$; Error of estimate=3.083);

YGOCLPL $=-34.59+0.453 \times \mathrm{B}-0.551 \times \mathrm{FMA}-0.369 \times$ P_OR_N + $0.149 \times$ N_POG_- $1.311 \times$ WITS + $0.749 \times$ MM
$\left(R^{2}=0.832 ; F_{(6.44)}=36.37 ; p<0.001 ;\right.$ Error of estimate=1.769); YGRES $=9.498-1.276 \times$ N_POG_- $4.754 \times A B$ NPOG $10.19 \times A N B+2.962 \times$ POR_GNS + $1.708 \times P N \_P O G-0.588$ $x R \_A S C+2.783 \times A \_N \_P O\left(R^{2}=0.581 ; F_{(7,43)}=8.51 ; p<0.001\right.$; Error of estimate $=6.368)$;

where, SNB (angle SNB) - is formed by lines S-N and N$B$ (the angle points to the anterior-posterior position of the lower jaw to the base of the skull); I (inclination angle, angle I) - angle of inclination of the upper jaw (spinal plane) to the nasal perpendicular); NAPOG (the angle of the skeletal obliquity or angle NaPog) - is formed by lines N-A and A-Pog; A_N_Po (distance A_N_Pog) - distance from point A to line N-Pog (the face plane, characterizes the degree of convexity of the face); PN_POG (distance PN_Pog) - distance from point Pog to nasal perpendicular $\overline{P N}$ (perpendicular line from point $\mathrm{N}$ to the line Po-Or).

Regression models of all other CT indicators that characterize the position of individual teeth in young men and women with orthognathic bite have a determination coefficient of less than 0.5 and therefore not significant for practical dentistry.

\section{Discussion}

Today, at the disposal of the orthodontist doctor available bracket systems with various unified characteristics that were proposed by various researchers [1]. With the availability and wider use of dental computer tomography, doctors have developed a tool to control the position of the roots of the teeth after orthodontic treatment, even by conducting only one preliminary diagnostic radiological examination [20].

By conducting an analytical analysis of the treatment outcomes, more and more studies appear that present unexpected findings. So Jain M. et al. [16] argues that the use of braces with different authoring prescriptions does not affect the overall clinical outcome and the quality of treatment depends entirely on the judgment of the clinician and his experience, and that the use of standard systems, even with given angular characteristics, still requires individual arc correction [34]. A number of studies prove the inconsistency of the angular characteristics of the standard braces that are obtained by teeth at the end of the orthodontic treatment $[4,26]$.

The existence of such a situation can be explained by the absence of taking into account the variations of the individual anatomy of the teeth when positioning the bracket [27], the presence of errors in various manufacturers, which under one type of prescription can produce different angular characteristics $[2,25]$ and the impossibility of using one standard and unified system for biological diversity various variations and types of anatomical structure of the toothjaw system. So, a number of studies indicate that the normative characteristics of the spatial position of the teeth differ significantly in different races and ethnic groups [18, 22] and require the study and development of updated indicators [32]. It is also noted that there is an individual variation regarding the angular positions of the teeth [17], 
which necessitates the development of individual prognostic techniques.

In our study, based on the peculiarities of the metric characteristics of the skull, which usually do not change during surgical and orthodontic treatment, as well as the parameters of the width, length, angles and position of the upper and lower jaws, which may be altered by orthodontic surgery, using the stepwise regression method with inclusion, in young men and women, reliable models of CT-indicators that characterize the position of individual teeth relative to each other, to the bony cranial structures and profile of the face are developed. It was established that in young men from 40 possible models, 23 were constructed with determination coefficient $R^{2}$ from 0.557 to 0.832 , while young women had only 8 models with determination coefficient $R^{2}$ from 0.581 to 0.832 . Moreover, in young men - out of 10 possible 9 models of vestibular-tongue inclination of corresponding teeth were constructed $\left(R^{2}\right.$ from 0.557 to 0.832 ); out of 10 possible 5 models of mesio-distal inclination of corresponding teeth ( $R^{2}$ from 0.558 to 0.769 ) were constructed; of the possible 14 constructed 6 models of rotation of the corresponding teeth ( $R^{2}$ from 0.579 to 0.737 ); and in young women - only 5 models of the vestibular-tongue inclination of the corresponding teeth $\left(R^{2}\right.$ from 0.603 to $0.665)$. In addition, in both in young men and women, models of the magnitude of the inter-incision angle $\left(R^{2} 0.748\right.$ in young men and 0.581 in young women), the magnitude of the angle of inclination of the lower canine in the jet plane $\left(R^{2}\right.$ respectively 0.729 and 0.793 ) and the values of the inclination of the closing plane relative to the palatal plane $\left(R^{2}\right.$ is respectively 0.808 and 0.832 ).

The analysis found that in young men models most often included - the WITS score, indicating a linear interjaw ratio in the anterior-posterior direction (7.0\%); angle GL_SNPOG, or the index of convexity of the soft tissue profile (5.4\%); distance S_E, maxillo-mandibular angle MM, defines the angle at which the upper jaw is located in relation to the lower jaw in the jet plane, angle NSBA (by

\section{References}

[1] Agrawal, K., Kangne, S., Ambekar, A., Joshi, Y., Marure, P. K., \& Khanapure, C. (2018). Evolution of Pre-Adjusted Edgewise Appliance in Orthodontics. MIDSR Journal of Dental Research, 1(1), 72-78.

[2] Alavi, S., \& Tajmirriahi, F. (2016). Assessment of dimensional accuracy of preadjusted metal injection molding orthodontic brackets. Dent. Res. J. (Isfahan), 13(5), 440-445. PMID: 27857770

[3] Athanasiou, A. E. (1997). Orthodontic cephalometry. London. Osby Wolfe.

[4] Castro, I. O., Fraz?o-Gribel, B., Alencar, A. H. G., ValladaresNeto, J., \& Estrela, C. (2018). Evaluation of crown inclination and angulation after orthodontic treatment using digital models : Comparison to the prescription of the brackets used. $J$. Orofac. Orthop., 79(4), 227-234. doi: 10.1007/s00056-0180136-2

[5] Coskun, I., \& Kaya, B. (2018). Cone Beam Computed Tomography in Orthodontics. Turk. J. Orthod., 31, 55-61. doi: 10.5152/
4,7\%); angle AB_NPOG, angle N_POG_, distance N_SE, coefficient N_SP_SP, which determines the ratio of the upper and lower facial heights, as well as the soft tissue facial angle P_OR_N (by 3.9\%). In young women most often models included - angle N_POG_(14.3\%); angle AB_NPOG $(10.2 \%)$; indicator WITS $(8.2 \%)$; angle MM, angle ANB, indicating the angular inter-jaw ratio in the anterior-posterior direction, as well as the length of the branch of the mandible R_ASC (by 6.1\%).

In further research, it is necessary to develop a computer program that will allow orthodontists to automatically calculate the necessary CT indicators that characterize the position of individual teeth relative to each other, to the bone cranial structures and profile of the face, which will enable the dentist to achieve the treatment of maximum physiological and aesthetic results.

\section{Conclusions}

1. In young men with normal occlusion close to orthognathic bite of 40 possible regression models of CT indicators that characterize the position of individual teeth relative to each other, to the bone cranial structures and profile of the face, 23 with a determination coefficient $R^{2}$ of 0.557 to 0.832 were constructed, and in young women only 8 models with determination coefficient $R^{2}$ from 0.581 to 0.832 .

2. In young men, among the metric characteristics of the skull, which usually do not change during surgical and orthodontic treatment, as well as the parameters of the width, length, angles and position of the upper and lower jaws that may be altered by orthodontic surgery models most commonly included - indicator WITS (7.0\%), angle GL_SNPOG (5.4\%); distance S_E, angle MM and angle NSBA (by 4.7\%), angle AB_NPOG, angle N_POG_, distance N_SE, coefficient N_SP_SP and angle P_OR_N (by $3.9 \%$ ); and in young women - angle N_POG_(14.3\%), angle AB_NPOG (10.2\%), indicator WITS $(8.2 \%)$, angle MM, angle ANB and length of the branch of the mandible R_ASC (by $6.1 \%$ ).

TurkJOrthod.2018.18020

[6] Dmitriev, M. O. (2016). Definition of normative cephalometric parameters by Steiner method for Ukrainian young men and women. World of Medicine and Biology, 3(57), 28-32.

[7] Dmitriev, M. O. (2017). Identification of normative cephalometric parameters based on $\mathrm{G}$. Schmuth method for young male and female Ukrainians. Reports of Morphology, 23(2), 288-292.

[8] Dmitriev, M. O., Chugu, T. V., Gerasymchuk, V. V., \& Cherkasova, O. V. (2017). Determination of craniometric and gnatometric indicators by A. M. Schvartz metod for Ukrainian boys and girls. Biomedical and Biosocial Anthropology, 29, 53-58.

[9] Dmitriev, M. O., Tikholaz, V. O., Shepitko, K. V., ShinkarukDykovytska, M. M., Androshchuk, O. V., Bobruk, S. V., \& Zakalata, T. R. (2018). Sexual dimorphism of normative cephalometric parameters determined by the Holdaway method in boys and girls of Podillia. World of Medicine and Biology, 2(64), 39-43. doi: 10.26724/2079-8334-2018-2-64-39-43

[10] Doroshenko, S. I., \& Kulginskiy, E. A. (2007). 
Teleroentgenography Basics. K.: Zdorov'ya.

[11] Downs, W. B. (1956). Analysis of the dentofacial profile. Angle Orthodontist, 26, 191-212.

[12] Gunas, I. V., Dmitriev, M. O., Tikholaz, V. O., ShinkarukDykovytska, M. M., Pastukhova, V. A., Melnik, M. P., \& Rudiy, Yu. I. (2018). Determination of normal cephalometric parameters by J. McNamara method for Ukrainian boys and girls. World of Medicine and Biology, 1(63), 19-22. doi: 10.26724/2079-8334-2018-1-63-19-22

[13] Gunas, I. V., Dmitriev, M. O., Prokopenko, S. V., ShinkarukDykovytska, M. M., \& Yeroshenko, G. A. (2017). Determination regulatory cephalometric options by the method of Tweed International Foundation for Ukrainian boys and girls. World of Medicine and Biology, 4(62), 27-31. doi: 10.26724/2079-83342017-4-62-27-31

[14] Holdaway, R. A. (1983). A soft-tissue cephalometric analysis and its use in orthodontic treatment planning. Part I. Am. J. Orthod., 84(1), 1-28. PMID: 6575614

[15] Holdaway, R. A. (1984). A soft-tissue cephalometric analysis and its use in orthodontic treatment planning. Part II. Am. J. Orthod., 85, 279-293. https://doi.org/10.1016/00029416(84)90185-4

[16] Jain, M., Varghese, J., Mascarenhas, R., Mogra, S., Shetty, S., \& Dhakar, N. (2013). Assessment of clinical outcomes of Roth and MBT bracket prescription using the American Board of Orthodontics Objective Grading System. Contemp. Clin. Dent., 4(3), 307-312. doi: 10.4103/0976-237X.118361

[17] Jain, S., Kiran, H. J., Neha, K., Bhattacharjee, D., Rana, S., \& Nayyar, A.S. (2017). Assessment of tip, torque, and tooth size discrepancies in Angle's class II division 2 malocclusion. International jornal of orofacial biology, 1(1), 4-12. doi:10.4103/ijofb.ijofb_9_16

[18] Kannabiran, P., Thirukonda, G. J., \& Mahendra, L. (2012). The crown angulations and inclinations in Dravidian population with normal occlusion. Indian jornal of dental research, 23(1), 53-58. doi: 10.4103/0970-9290.99039

[19] Kapila, S., Conley, R. S., \& Harrell, W. E. Jr. (2011). The current status of cone beam computed tomography imaging in orthodontics. Dentomaxillofac. Radiol., 40, 24-34. doi: 10.1259/dmfr/12615645

[20] Lee, R. J., Pi, S., Park, J., Nelson, G., Hatcher, D., \& Oberoi, S. (2018). Three-dimensional evaluation of root position at the reset appointment without radiographs: a proof-of-concept study. Progress in Orthodontics, 19(1), 15. https://doi.org/ 10.1186/s40510-018-0214-4

[21] Leman, K., \& Helvig, E. (1999). Basics of therapeutic and prosthetic dentistry. Lvov: GalDent.

[22] Lombardo, L., Perri, A., Arreghini, A., Latini, M., \& Siciliani, G. (2015). Three-dimensional assessment of teeth first-, secondand third-order position in Caucasian and African subjects with ideal occlusion. Progress in Orthodontics, 16, 11. doi: 10.1186/s40510-015-0086-9

[23] Mah, J. K., Huang, J. C., \& Choo, H.-R. (2010). Practical Applications of Cone-Beam Computed Tomography in Orthodontics. The Journal of the American Dental Association, 141, 7-13. https://doi.org/10.14219/ jada.archive.2010.0361

[24] McNamara, J. A. Jr. (1984). Amethod of cephalometric evaluation. Am. J. Orthod., 86(6), 449-469. PMID: 6594933

[25] Mendonca, M. R., Verri, A. C., Fabre, A. F., \& Cuoghi, O. A. (2014). Analysis of mesiodistal angulations of preadjusted brackets. Braz. Oral. Res., 28(1), 1-8. http://dx.doi.org/ 10.1590/1807-3107BOR-2014.vol28.0038

[26] Mittal, M., Thiruvenkatachari, B., Sandler, P. J., \& Benson, P. E. (2015). A three-dimensional comparison of torque achieved with a preadjusted edgewise appliance using a Roth or MBT prescription. Angle Orthod., 85, 292-297. doi: 10.2319/122313941

[27] Papageorgiou, S. N., Sifakakis, I., Keilig, L., Patcas, R., Affolter, S., Eliades, T., \& Bourauel, C. (2017). Torque differences according to tooth morphology and bracket placement: a finite element study. European Journal of Orthodontics, 39(4), 411418. https://doi.org/10.1093/ejo/cjw074

[28] Plooij, J. M., Maal, T. J., Haers, P., Borstlap, W. A., KuijpersJagtman, A. M., \& Berge, S. J. (2011). Digital three-dimensional image fusion processes for planning and evaluating orthodontics and orthognathic surgery. A systematic review. Int. J. Oral Maxillofac. Surg., 40(4), 341-352. doi: 10.1016/ j.jom.2010.10.013

[29] Schmuth, G. P. F. (1971). Methodische Schwierigkeiten bei der Anwendung der Rontgenkephalometrie in der Kieferorthopadie. Fortschritte der Kieferorthopadie, 32(2), 317-325.

[30] Schwarz, A. M. (1960). Rontgenostatics; practical evaluation of the tele-X-ray-photo. Publisher: Brooklyn, N.Y.: Leo L. Bruder.

[31] Steiner, C. C. (1959). Cephalometrics in clinical practice. Angle Orthod., 29, 8-29.

[32] Tong, H., Kwon, D., Shi, J., Sakai, N., Enciso, R., \& Sameshima, G. (2012). Mesiodistal angulation and faciolingual inclination of each whole tooth in 3-dimensional space in patients with near-normal occlusion. American Journal of Orthodontics and Dentofacial Orthopedics, 141(5), 604-617. doi: 10.1016/ j.ajodo.2011.12.018

[33] Tweed, C. H. (1954). The Frankfort-Mandibular Incisor Angle (FMIA) in Orthodontic Diagnosis, Treatment Planning and Prognosis. Angle Orthod., 3, 121-169.

[34] van Loenen, M., Degrieck, J., de Pauw, G., \& Dermaut, L. (2005). Anterior tooth morphology and its effect on torque. European Journal of Orthodontics, 27, 258-262. doi:10.1093/ ejo/cji007

\section{ВИЗНАЧЕННЯ ІНДИВІДУАЛЬНИХ КУТОВИХ ХАРАКТЕРИСТИК ПОЛОЖЕНЬ ЗУБІВ ЗА ДАНИМИ КОМП'ЮТЕРНОЇ ТОМОГРАФІЇ УКРАЇНСЬКИХ ЮНАКІВ І ДІВЧАТ ІЗ ОРТОГНАТИЧНИМ ПРИКУСОМ \\ Дмітрієв М.О., Волков К. С., Глушак А. А., Кириченко Ю. В., Балинська М. В., Чугу Т. В., Ковальчук О. I.}

Відсутність можливості визначення індивідуальних нормативних кутових характеристик положення зубів та технічне забезпечення їх контролю часто не призводить до отримання очікуваного результату і в кожному випадку потребує індивідуалізації, бачення якої базується, як правило, на досвіді та інтуїиї лікаря. Для вирішення такої ситуації окрім вдосконалення протоколів позиціювання незнімної апаратури лікарю необхідно мати можливість чіткого визначення індивідуальних кутових характеристик зубощелепної системи. Мета дослідження - шляхом вивчення ком'ютернотомографрічних та цефалометричних показників і проведення прямого покрокового регресійного аналізу розробити у юнаків та дівчат України з ортогнатичним прикусом математичні моделі індивідуальних кутових положень зубів. За допомогою пристрою Veraviewepocs 3D, Моріта (Япония) у 38 юнаків (віком від 17 до 21 року) та 55 дівчат (віком від 16 до 20 років) з нормальною оклюзією наближеною до ортогнатичного прикусу були отримані та проаналізовані дентальні томограми та бокові телерентгенограми. Цефралометричні точки та вимірювання проводили згідно рекомендацій A. M. Schwarz, J. McNamara, 
W. B. Downs, R. A. Holdway, G. P. F. Schmuth, C. C. Steiner ma C. H. Tweed. Анатомічні точки визначалися з урахуванням рекомедацій A. E. Athanasiou та C. І. Дорошенко і Є. А. Кульгинского. Проводили моделювання КТ-показників які характеризують положення окремих зубів по відношенню один до одного, до кісткових черепних структур та профілю обличя в юнаків і дівчат із ортогнатичним прикусом в залежності від метричних характеристик черепа, які зазвичай не змінюються в ході хірургічного та ортодонтичного лікування, а також показників ширини, довжини, кутів і положення верхньої й нижньої щелеп які можливо змінювати за допомогою ортодонтичної хірургії. Статистична обробка отриманих результатів проведена в ліцензійному пакеті "Statistica 6,0" з використанням прямого покрокового регресійного аналізу. Встановлено, що в юнаків із 40 можливих моделей побудовано 23 з коефіцієнтом детермінації $R^{2}$ від 0,557 до 0,832, а у дівчат лише 8 моделей з коефріцієнтом детермінації $R^{2}$ від 0,581 до 0,832. Причому, в юнаків - із 10 можливих побудовано 9 моделей присінково-язикового нахилу відповідних зубів $\left(R^{2}\right.$ від 0,557 до 0,832); із 10 можливих побудовано 5 моделей мезіо-дистального нахилу відповідних зубів ( $R^{2}$ від 0,558 до 0,769); із 14 можливих побудовано 6 моделей ротації відповідних зубів ( $R^{2}$ від 0,579 до 0,737); а у дівчат - лише 5 моделей присінковоязикового нахилу відповідних зубів $\left(R^{2}\right.$ від 0,603 до 0,665). Крім того, як в юнаків, так і у дівчат побудовані моделі величини міжрізцевого кута ( $R^{2}$ 0,748 в юнаків і 0,581 у дівчат), величини кута нахилу нижнього ікла у стріловій площині $\left(R^{2}\right.$ відповідно 0,729 і 0,793) та величини нахилу змикальної площини відносно піднебінної площини ( $R^{2}$ відповідно 0,808 і 0,832). При аналізі встановлено, що в юнаків найбільш часто до моделей входили - показник WITS (7,0\%); куm GL_SNPOG (5,4\%); відстань S_E, кут MM, кут NSBA (по 4,7\%); кут AB_NPOG, куm N_POG_, відстань N_SE, коефріцієнт N_SP_SP, кут P_OR_N (по 3,9\%). У дівчат найбільш часто до моделей входили - кут N_POG_(14,3\%); кут AB_NPOG (10,2\%); показник WITS (8,2\%); кут MM, кут ANB, довжина гілки нижньої щелепи R_ASC (по 6,1\%). Таким чином в роботі за допомогою методу покрокової регресії з включенням, у українців юнацького віку, на основі особливостей ком'ютернотомографрічних та телерентгенографрічних показників розроблені та проаналізовані достовірні моделі ком'ютернотомографрічних індивідуальних лінійних кутових характеристик положення зубів необхідних для побудови коректної тривимірної геометрії зубних дуг.

Ключові слова: регресійний аналіз, присінково-язиковий нахил зуба (торк), мезіодистальний нахил зуба (ангуляція), поворот зуба (ротація), комп'ютерна томографрія, телерентгенографрія, юнаки, дівчата, ортогнатичний прикус.

\section{ОПРЕДЕЛЕНИЕ ИНДИВИДУАЛЬНЫХ УГЛОВЫХ ХАРАКТЕРИСТИК ПОЛОЖЕНИЙ ЗУБОВ ПО ДАННЫМ КОМПЬЮТЕРНОЙ ТОМОГРАФИИ УКРАИНСКИХ ЮНОШЕЙ И ДЕВУШЕК С ОРТОГНАТИЧЕСКИМ ПРИКУСОМ \\ Дмитриев Н. А., Волков К. С., Глушак А. А., Кириченко Ю. В., Балынская М. В., Чугу Т. В., Ковальчук А. И.}

Отсутствие возможности определения индивидуальных нормативных угловых характеристик положения зубов и техническое обеспечение их контроля часто не приводит к получению ожидаемого результата и в каждом случае требует индивидуализации, видение которой базируется, как правило, на опыте и интуиции врача. Для решения такой ситуации кроме совершенствования протоколов позиционирования несъемной аппаратуры врачу необходимо иметь возможность четкого определения индивидуальных угловых характеристик зубочелюстной системы. Цель исследования - путем изучения компьютернотомографических и цефралометрических показателей и проведения прямого пошагового регрессионного анализа разработать у юношей и девушек Украины с ортогнатическим прикусом математические модели индивидуальных угловых положений зубов. С помощью устройства Veraviewepocs 3D, Морита (Япония) у 38 юношей (в возрасте от 17 до 21 года) и 55 девушек (в возрасте от 16 до 20 лет) с нормальной окклюзией приближенной к ортогнатическому прикусу были получены и проанализированы дентальные томограммы и боковые телерентгенограммы. Цефалометрические точки и измерения проводили согласно рекомендациям A. M. Schwarz, J. McNamara, W. B. Downs, R. A. Holdway, G. P. F. Schmuth, C. C. Steiner u C. H. Tweed. Анатомические точки определялись с учетом рекомендаций A. E. Athanasiou и С. И. Дорошенко и Е. А. Кульгинского. Проводили моделирование КТ-показателей характеризующих положение отдельных зубов по отношению друг к другу, к костным черепным структурам и профрилю лица у юношей и девушек с ортогнатическим прикусом в зависимости от метрических характеристик черепа, которые обычно не меняются в ходе хирургического и ортодонтического лечения, а также показателей ширины, длины, углов и положение верхней и нижней челюстей которые можно изменять с помощью ортодонтической хирургии. Статистическая обработка полученных результатов проведена в лицензионном пакете "Statistica 6,0" c использованием прямого пошагового регрессионного анализа. Установлено, что у юношей из 40 возможных моделей построено 23 с коэфрфициентом детерминации $R^{2}$ от 0,557 до 0,832, а у девушек только 8 моделей с коэфрфициентом детерминации $R^{2}$ от 0,581 до 0,832. Причем, у юношей - из 10 возможных построено 9 моделей преддверно-языкового наклона соответствующих зубов ( $R^{2}$ от 0,557 до 0,832); из 10 возможных построено 5 моделей мезио-дистального наклона соответствующих зубов $\left(R^{2}\right.$ от 0,558 до 0,769); из 14 возможных построено 6 моделей ротации соответствующих зубов $\left(R^{2}\right.$ от 0,579 до 0,737); а у девушек - всего 5 моделей преддверно-языкового наклона соответствующих зубов ( $R^{2}$ от 0,603 до 0,665). Кроме того, как у юношей, так и у девушек построены модели величины межрезцового угла ( $R^{2} 0,748$ у юношей и 0,581 у девушек), величины угла наклона нижнего клыка в стреловой плоскости ( $R^{2}$ соответственно 0,729 и 0,793) и величины наклона замыкающей плоскости относительно небной плоскости ( $R^{2}$ соответственно 0,808 и 0,832). При анализе установлено, что у юношей наиболее часто к моделям входили - показатель WITS (7,0\%); угол GL_SNPOG (5,4\%); расстояние S_E, угол МM, угол NSBA (по 4,7\%); угол $A B \_N P O G$, угол $N \_P O G \_$, расстояние $N \_S E$, коэфрфициент $N \_S P \_S P$, угол $P \_O R \_N$ (по 3,9\%). У девушек наиболее часто к моделям входили - угол N_POG_(14,3\%); угол AB_NPOG (10,2\%); показатель WITS (8,2\%); угол МM, угол ANB, длина ветви нижней челюсти R_ASC (по 6,1\%). Таким образом в работе с помощью метода пошаговой регрессии с включением, в украинцев юношеского возраста, на основе особенностей компьютерно-томографических и цефалометрических показателей разработаны и проанализированы достоверные модели компьютерно-томографических индивидуальных линейных угловых характеристик положения зубов необходимых для построения корректной трехмерной геометрии зубных дуг.

Ключевые слова: регрессионный анализ, преддверно-языковой наклон зуба (торк), мезиодистальный наклон зуба (ангуляция), поворот зуба (ротация), компьютерная томография, телерентгенография, юноши, девушки, ортогнатический прикус. 